\title{
SUBSÍDIOS DE ANÁLISE DA TRIBUTAÇÃO DO JOGO EM PORTUGAL
}

\author{
A BRIEF ANALYSIS ON GAMBLING TAXATION IN PORTUGAL
}

\author{
Altina Rento ${ }^{1}$ \\ João Paulo Peixoto ${ }^{2}$
}

RESUMO: Em Portugal, os jogos de fortuna ou azar constituem monopólio do Estado. A sua prática, circunscrita no essencial aos casinos e sujeita a forte regulação, é explorada em regime de concessão e adjudicada a empresas seleccionadas pelo Estado mediante concurso público. Incide sobre os jogos de fortuna ou azar uma tributação especial, cujo modelo de imposto, definido através de complexas fórmulas, se caracteriza nomeadamente pela previsão de taxas diferentes consoante a tipologia dos jogos e as zonas de implantação dos casinos. As receitas provenientes do imposto especial de jogo revertem fundamentalmente para fins de natureza turística, representando uma importante contribuição para o desenvolvimento das áreas de implantação dos casinos.

PALAVRAS-CHAVE: Jogos de fortuna ou azar; Casinos; Imposto especial de jogo.

ABSTRACT: Gambling business is, in Portugal, a State monopoly. Its practice, confined essentially to casinos and subject to strong regulation, takes place under a concession, awarded to companies selected by the State through a public proceeding. Gambling exploitation is subject to special taxation, which model, defined by complex formulas, is namely characterized by the existence of different tax rates according to the type of games and the casinos' locations. Revenues from the special gambling tax revert primarily for the

\footnotetext{
1 Mestranda em Gestão e Negócios no Instituto de Estudos Superiores Financeiros e Fiscais (Portugal). Inspectora Superior Principal da Administração Pública. Ex-Inspectora da Inspecção-Geral deJogos. Master of Business Administration em Finanças (Especialização em Gestão Internacional) peloInstituto de Estudos Superiores Financeiros e Fiscais (Portugal). Diploma de Estudos Avançados (Pós-Graduação) e Auditora de Defesa Nacional pelo Instituto da Defesa Nacional (Portugal). Pós-Graduadaem Gestão Financeira Internacional pelo Instituto de Estudos Superiores Financeiros e Fiscais (Portugal). Licenciada em Direito pela Universidade de Lisboa (Portugal). E-mail: altinarento@gmail.com.

2 Presidente do Instituto de Estudos Superiores Financeiros e Fiscais (Portugal). Investigador e Docente Universitário. Master of Business Administration e Mestre em Gestão de Empresas pela Universidade do Porto (Portugal). Licenciatura em Economia pela Universidade do Porto (Portugal). Especialista em Mercados Financeiros através de Provas Públicas.
} 
tourism sector, representing a major contribution to the development of the areas where casinos are located.

KEYWORDS: Gambling; Casinos; Special gambling tax.

\section{INTRODUÇÃO}

Considerado social e eticamente reprovável, o jogo de fortuna ou azar (doravante designado também e indistintamente como jogo) foi actividade ilícita até finais da década de vinte do século passado ${ }^{3}$.

O Decreto n. ${ }^{\circ} 14643$, de 3 de Dezembro de 1927, que operou a mudança, começou por definir o jogo de fortuna ou azar como aquele cujos resultados são contingentes por não dependerem da destreza, inteligência ou cálculo do jogador (art..$^{\circ} 1^{\circ}$ ), circunscrevendo a respectiva prática aos casinos e a sua exploração a empresas às quais o Estado português adjudicasse a concessão. Um dos ingredientes de tal mudança consistiu na tributação, pela primeira vez, da actividade do jogo lícito, valorizando-se a expectativa de que tal tributação acarretaria a diminuição da oferta do jogo e, consequentemente, a produção dos indesejáveis efeitos, pessoais e sociais, que a sua prática acarreta ${ }^{4}$.

A actual Lei do Jogo (Dec.-Lei n. ${ }^{\circ}$ 422/89, de 2 de Dezembro, alterada e republicada pelo Dec.-Lei n. ${ }^{\circ}$ 114/2011, de 30 de Novembro) manteve o essencial do traçado anterior, com algumas inovações ao nível do conceito legal de jogo, da responsabilização das empresas concessionárias relativamente à exploração e prática do jogo, e das condições de acesso às salas de jogo. Depois de uma breve passagem pelas razões motivadoras do rompimento

\footnotetext{
3 Das Ordenações Manuelinas (Livro V, título XLVIII, § 3) consta uma aparente excepção àquela proibição, relativamente aos jogos de tábulas em tabuleiros; a excepção é tão-só aparente, porque estes jogos não são jogos de fortuna ou azar, dado não dependerem exclusivamente ou fundamentalmente do acaso. Em termos globais, e a propósito da ancestralidade do jogo, sua histórica proibição e posterior aceitação, ver por todos, Brenner, Reuven, e Brenner, Gabrielle: Spéculation et jeux de hasard: Une histoire de l'homme par le jeu, Paris, Presses Universitaires de France, 1993, e Camillieri, Sébastien: Les finances publiques et le jeu, Thèse de doctorat, Université Jean Moulin Lyon 3, décembre 2008, p. 8, consultado em 29 de Maio de 2014, em <http://theses.univ-lyon3.fr/documents/getpart.php?id=1472\&action=pdf>, DEUS, José Pereira de, e Lé, António Jorge: O Jogo em Portugal, Coimbra, Minerva, 2001 e PINHEIRO, Januário, Lei do Jogo, Anotada e Comentada, Coimbra, Almedina, 2006, p. 388-389.

${ }^{4}$ Os malefícios do jogo são profundos. Estudos realizados apontam para a possibilidade de transmissão intergeracional dos efeitos do jogo, estando os filhos dos jogadores compulsivos mais propensos à adição ao jogo (Barnes, Steve: "The Real Cost of Casinos: A Health Equity Impact Assessment", Wellesley Institute, January 2013, p. 4, consultado em 13 de Fevereiro de 2014, em <http://www.wellesleyinstitute.com/wpcontent/uploads/2013/01/Real-Cost-of-a-Casino_Wellesley-Institute_2013.pdf >).
} 
secular da criminalização do jogo, que conduziu à legalização da sua exploração e prática (embora fortemente controladas pelo Estado), analisaremos, segundo a metodologia jurídica, o respectivo regime de tributação.

A tributação do jogo mantém hoje as características fundamentais do regime instituído em 1927, destacando-se, todavia, algumas alterações introduzidas nas taxas aplicáveis, cujas percentagens diferem em razão dos jogos disponibilizados pelos casinos e das particularidades das várias zonas de jogo concessionadas.

Neste trabalho abordaremos sucessivamente a natureza do imposto especial de jogo, os sujeitos da relação tributária, a matéria colectável, o quadro de taxas e respectiva cobrança, a afectação das receitas e a fiscalização do imposto. Finalizar-se-á com uma apreciação crítica global deste sistema tributário.

\section{DA LEGALIZAÇÃO E TRIBUTAÇÃO DO JOGO}

Admitida a impossibilidade da erradicação do jogo de fortuna ou azar, mas assumindo que a sua legalização poderia traduzir-se numa importante fonte receitas públicas por via da tributação $^{5}$, o Estado português optou, com o Decreto n. ${ }^{\circ} 14643$, por autorizar a prática do jogo, circunscrevendo-o, porém, aos casinos (estabelecimentos especialmente criados para o efeito e obrigatoriamente implantados em áreas qualificadas como zonas de jogo) ${ }^{6}$. O jogo só poderia ser explorado por empresas privadas, com sede social em Portugal e obrigatoriamente constituídas sob a forma de sociedades anónimas de responsabilidade limitada ( $\operatorname{art}^{\circ}{ }^{\circ} 6^{\circ}$ ), às quais a actividade viesse a ser concessionada, ficando tal actividade sujeita a estreita regulação e forte controlo do Estado. Em quaisquer outras circunstâncias, o exercício do jogo

\footnotetext{
${ }^{5}$ Globalmente considerado, o sector do jogo representa um importante papel económico tanto na Europa como nos Estados Unidos e tem vindo a crescer na Austrália, Nova Zelândia e Canadá (principalmente depois da legalização das máquinas de jogo electrónicas). Relativamente à União Europeia e aos Estados Unidos da América, dados de 2006 revelam que o montante apostado em 2003 teve um peso nos seus produtos internos brutos de $0,52 \%$ e de $0,65 \%$, respectivamente, (embora com diferente distribuição dos gasto em apostas nas lotarias e nos jogos em casinos: na UE jogou-se $45 \%$ nas lotarias contra os $24 \%$ dos EUA; nos jogos em casinos foram gastos $15 \%$ na UE e 58\% nos EUA) (Cnossen, Sijbren (ed.), Forrest, David, e Smith, Stephen: Taxation and Regulation of Smoking, Drinking and Gambling in the European Union, The Hague, CPB Netherlands Bureau for Economic Policy Analysis, 2009, p. 72).

${ }^{6}$ Para melhor compreensão da evolução legislativa que envolveu a exploração e prática do jogo em Portugal, ver Clímaco, Maria Isabel Namorado, "Os Jogos de Fortuna ou Azar - O lazer tolerado ou o 'vício' legalizado?" in Sanches, J. L. Saldanha e Martins, António: Homenagem a José Guilherme Xavier de Basto, Coimbra Editora, 2006, pp. 484-486.
} 
permanecia proibido. Com esta opção, o Estado arrecadaria generosas receitas para o erário público $^{7}$, acautelando também melhor os interesses dos jogadores e suas famílias, contribuindo assim para a diminuição do jogo clandestino e da acção criminosa que frequentemente lhe está associada ${ }^{8}$ (branqueamento de capitais, tráfico, corrupção, etc.).

Os casinos deveriam ser estabelecimentos modelares e luxuosos, capazes de oferecer comodidade e conforto aos frequentadores: tais estabelecimentos haviam de ser dotados de salões destinados à prática do jogo, com entradas e saídas totalmente independentes e dispostos de forma a que nada fosse visível do seu exterior; de salões para recreio, diversão e cultura (designadamente para dança, leitura, exposições, conferências, teatro, cinema); de restaurantes; de parques com campos de jogos desportivos e jardins; de esplanadas sobre o mar; etc. A lei determinava ainda que, em cada zona de jogo permanente, caso não existissem equipamentos hoteleiros com idênticos requisitos de luxo, anexos aos casinos ou na proximidade destes, as empresas concessionárias deveriam prover à sua construção. Ora, pese embora a variedade de actividades desenvolvidas em casinos, somente a exploração do jogo era sujeita ao imposto especial de jogo, incidindo sobre as demais a tributação geral aplicável às actividades económicas.

Consta do art. $^{\circ} 44 .^{\circ}$ do Decreto n. ${ }^{\circ} 14643$ que o exercício da indústria do jogo seria concessionado mediante o pagamento ao Estado de uma renda anual fixa, ficando sujeito ao pagamento do imposto sobre o jogo e não lhe sendo aplicável outra tributação. O imposto especial de jogo recairia sobre duas parcelas: a primeira incidindo sobre os jogos efetivamente disponibilizados (bancas abertas ao jogo), contabilizada em função do capital em giro (importância com que a banca se inicia, acrescida dos valores com que seja reforçada - art. $^{\circ}$ 46..$^{\circ}$ n. $.^{\circ} .^{\circ}$ ); e a segunda aplicada aos resultados brutos obtidos pelas concessionárias. Os bilhetes de acesso às salas de jogo também seriam tributados. Nos últimos quinze anos do prazo das concessões far-se-ia o apuramento total dos resultados alcançados pelas empresas concessionárias, os quais, após deduzidos os prejuízos sofridos e os impostos pagos ao Estado pelos jogos jogados, seriam tributados de acordo com um figurino de taxas progressivas.

\footnotetext{
7 Pinto, Mota, Monteiro, Pinto, e Silva, Calvão da: Jogo e Aposta - Subsídios de Fundamentação Ética e Histórico-Jurídica, apontamentos copiografados, Lisboa, Católica Portuguesa, s.d., p. 133.

8 Gomes, Maria Margarida Carqueijeiro Tomaz, A Política Pública das Lotarias, Instituto Superior de Economia e Gestão da Universidade Técnica de Lisboa, 2007, p. 17.
} 
Os montantes pagos ao Estado por conta da exploração dos jogos de fortuna ou azar seriam consignados em grande parte à receita geral do Estado e, embora em distintas e menores proporções, à assistência pública; às câmaras municipais do concelho da respectiva zona de jogo; às câmaras municipais das regiões do turismo identificadas oficialmente; constituindo também dotação especial das estradas de maior acesso aos centros e regiões do turismo. Tais verbas eram vistas como um precioso contributo para o desenvolvimento turístico das regiões onde o jogo estava implantado, e suas áreas limítrofes, vindo as concessionárias, por força dos respectivos contratos, a assumir encargos com a construção de equipamentos como casinos e hotéis, bem como com a promoção de actividades ligadas à cultura e ao lazer 9 .

A fiscalização do cumprimento das normas reguladoras da exploração dos jogos de fortuna ou azar ficou a cargo de agentes policiais com delegação do Ministro do Interior ou de quaisquer funcionários superiores da polícia de segurança pública, quando fardados; dos agentes especiais do Ministério do Interior, "encarregados de vigiar se os empregados nas mesas pagam mal, se se limitam à parada máxima e tudo o mais que possa interessar ao Estado" (art. ${ }^{\circ} 35 .^{\circ}$, n. $^{\circ}$ 2, do Decreto n. ${ }^{\circ}$ 14643); e dos funcionários do Ministério das Finanças, em matéria tributária, "de modo a acautelar os interesses fiscais do Estado e a conseguir a cobrança integral das receitas criadas" $\left(\operatorname{art}^{\circ} 35^{\circ}\right.$, n. $\left.^{\circ} 3\right)$.

\footnotetext{
9 Hoje, como dantes, as regiões com implantação de casinos são especialmente atingidas pelos efeitos nefastos do jogo; a canalização para aquelas de grande parte das receitas obtidas com a tributação do jogo representa, por um lado, o reconhecimento dessa evidência, e por outro, a tentativa do Estado em as compensar com recursos que contribuam para o seu desenvolvimento (por todos, Grinols, Earl L., e Mustard, David B.: "Business Profitability versus Social Profitability: Evaluating Industries with Externalities, The Case of Casinos", Managerial and Decision Economics, 2001, Vol. 22, pp. 143-162, pp. 148-155). No entanto há quem questione a importância desse benefício, atenta a importância dos custos sociais provocados pelos jogos de fortuna ou azar (Erreguerena Albaitero, José Miguel: "Aspectos fiscales de los juegos de azar en México", in Mora-Donatto, C. (coord.): Juegos de azar. Una visión multidisciplinaria, México, Universidad Nacional Autónoma de México, 2010, pp. 133-163, p. 137); mas nem aqueles que se opõem ao jogo ignoram o facto de o desenvolvimento da actividade ser gerador de emprego e de não negligenciáveis receitas, com impactos positivos noutras indústrias em especial nas de índole turística (Zornoza Pérez, Juan: "La tributación de los juegos de azar: Una perspectiva comparada", in Mora-Donatto, C. (coord.): Juegos de azar. Una visión multidisciplinaria, México, Universidad Nacional Autónoma de México, 2010, pp. 165-182, p. 165). A rigorosa avaliação sócio-económica dos custos do jogo de fortuna ou azar versus seus benefícios terá de obedecer a um profundo estudo sobre todos os elementos em presença, por recurso a uma adequada metodologia. Identificando vários tipos de impacto que o jogo provoca, Massin indica-nos um caminho que permitirá uma séria reflexão sobre esta temática (Massin, Sophie: "Étude socio-économique des jeux de hasard et d'argent en France", Rapport d'étape no 2, Observatoire des Jeux, 20 février 2013, pp. 8-12, consultado em 16 de Junho de 2014, em <http://www.economie.gouv.fr/files/Etude\%20économique\%20rapport\%20d'etape\%202.pdf >).
} 
O jogo encontra-se actualmente previsto no art. ${ }^{\circ} 1245 .^{\circ}$ do Código Civil português, cujo normativo, sem cuidar de definir o conceito, estatui que o jogo e a aposta (figuras que aparentemente distingue, sem todavia delimitar os seus contornos) não são contratos válidos e, como tal, não constituem fonte de obrigações civis, gerando, quando lícitos, meras obrigações naturais (ressalvada a existência de legislação especial); o art. $^{\circ} 1247 .^{\circ}$ do mesmo Código remete o respectivo tratamento jurídico para legislação especial.

A actual Lei do Jogo (Dec.-Lei n. ${ }^{\circ}$ 422/89, de 2 de Dezembro, alterado e republicado pelo Dec.-Lei n. ${ }^{\circ}$ 114/2011, de 30 de Novembro) define o jogo de fortuna ou azar como aquele cujo resultado é contingente por assentar exclusiva ou fundamentalmente na sorte (art. ${ }^{\circ}$ $\left.1 .^{o}\right)^{10} 11$, mantendo o paradigma anteriormente desenhado, que consistia na permissão da respectiva prática12 e sua circunscrição aos casinos (a que vieram a acrescer as salas de bingo fora dos casinos), estes explorados por empresas às quais o Estado adjudique as respectivas concessões 13 .

10 O jogo de fortuna ou azar foi também doutrinariamente definido como aquele jogo em que o jogador compromete uma parte do seu património na esperança de obter um ganho (Camillieri, op cit., p. 11).

11 O jogo de fortuna ou azar foi também doutrinariamente definido como aquele jogo em que o jogador compromete uma parte do seu património na esperança de obter um ganho (Camillieri, op cit., p. 11).

12 Tem-se assistido nos últimos anos a uma crescente tolerância ao jogo a nível global, embora os malefícios que lhe estão associados aconselhariam à sua restrição, ou mesmo proibição (Pessanha, Luís: "O Jogo de Fortuna e Azar e a Promoção do Investimento em Macau", Administração: Revista da Administração Pública de Macau, 2007-3ㅜㄴ, Vol. XX, № 77, pp. 847-888, p. 866). Tal tolerância é justificada com o argumento de que a proibição do jogo empurraria irremediavelmente os jogadores para o jogo clandestino, afirmando-se que os mecanismos de regulação permitirão minimizar os apontados custos sociais; no entanto, e malgrado os benefícios que advêm da canalização cirúrgica das receitas geradas pelo jogo, tais benefícios não são, na óptica de muitos, suficientes para compensar os custos trazidos pela indústria do jogo. Por todos, Jimenez Rea, Ovidio: Incidencia contable y tributaria del juego en casinos y máquinas tragamonedas en los fines extrafiscales del Estado, Tesis para optar el Grado Académico de Magister en Contabilidad con mención en Política y Administración Tributaria, Universidad Nacional Mayor de San Marcos, Facultad de Ciencias Contables, Lima (Perú), 2012, p. 50, $\begin{array}{lllllll}\text { consultado em } & 12 & \text { de } & \text { Fevereiro } & \text { de } & 2014, & \text { em }\end{array}$ <http://cybertesis.unmsm.edu.pe/bitstream/cybertesis/2664/1/jimenez_ro.pdf> e Erreguerena Albaitero, op. cit., p. 137. E está longe de ser pacifico o entendimento de que a regulação prossegue objectivos claros, pois, em contraste com muitas áreas da economia, a discussão à volta da política dos jogos pouco atenção presta ao bem estar dos respectivos consumidores, preocupando-se essencialmente com as receitas fiscais. Por todos, Zornoza Pérez, op. cit., p. 166, e Cnossen, op. cit., p. 77).

13 A não adjudicação da exploração do jogo a empresas com sede fora de um Estado Membro tem vindo a ser considerada compatível com o direito da União Europeia pelo Tribunal de Justiça, por razões imperiosas de interesse geral, tais como a protecção dos consumidores e a prevenção da fraude, bem como a prevenção das perturbações da ordem social em geral (Ac. TJUE 8 de Setembro de 2010, Liga Portuguesa de Futebol Profissional e Bwin International Ltd / Departamento de Jogos da Santa Casa da Misericórdia de Lisboa, C42/07, c. $\quad$ n. $^{\circ} 56, \quad$ consultado em 25 de Abril em <http://curia.europa.eu/juris/document/document.jsf?text=\&docid=77072\&pageIndex=0\&doclang=PT\&mode=ls

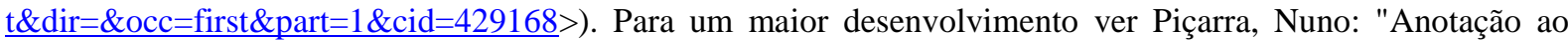
acórdão do Tribunal de Justiça da União Europeia, de 8 de Setembro de 2009, Liga Portuguesa de Futebol Profissional e Bwin International Ltd contra Departamento de Jogos da Santa Casa da Misericórdia de Lisboa, C42/07", in Duarte, Maria Luísa e. a. (coord.): 20 Anos de Jurisprudência da União sobre Casos Portugueses. O 
As receitas provenientes da exploração do jogo, bem como as geradas por outras actividades a que as empresas concessionárias se encontrem adstritas por força da concessão, continuam sujeitas apenas ao imposto especial de jogo. As inovações introduzidas reflectiramse essencialmente num acréscimo da responsabilização das concessionárias quanto ao respeito pela legalidade e correcção da exploração e prática do jogo (em contrapartida da oferta de melhores condições para um exercício mais rentável da actividade) e na adequação das condições de acesso às salas de jogo ao princípio fundamental da liberdade, consagrado designadamente nos art. ${ }^{\circ}$ s $2 .^{\circ}, 9 .^{\circ}$, al. b) $, 18 .^{\circ}, 20 .^{\circ}$, n. $^{\circ} 5,21 .^{\circ}, 22 .^{\circ}, 27 .^{\circ}$ e $288 .^{\circ}, a l . d$ ), da Constituição da República Portuguesa (CRP), por um lado, sem prejuízo do acentuar do princípio da reserva de admissão visando um melhor nível de frequência das salas.

Os valores pagos aos jogadores a título de prémio não são tributados (excepção feita ao jogo do bingo $\left.{ }^{14}\right)$. Tal opção legislativa corporiza uma medida de pendor assaz pragmático, podendo ter alguma sustentação no facto de a mera perspectiva da interrupção do jogo no final de cada jogada (para cálculo e registo dos valores relativos aos prémios) se apresentar como algo de difícil execução e até potencialmente destruidor de vários jogos ${ }^{15}$.

A fiscalização do imposto especial de jogo, bem como do imposto incidente sobre as receitas cobradas pelos acessos às respectivas salas, continua na esfera de competências do organismo do Estado com tutela sobre o jogo, mantendo-se, nas atribuições desse organismo, as funções de inspecção da exploração e prática do jogo e das obrigações contratuais a cargo das concessionárias. Os restantes impostos aplicáveis às empresas adjudicatárias continuam a ser fiscalizados pelo organismo do Estado com superintendência no sector tributário.

\section{DA NATUREZA DO IMPOSTO ESPECIAL DE JOGO}

que fica do diálogo entre os juízes portugueses e o Tribunal de Justiça da União Europeia, Lisboa, 2011, pp. 311 334.

${ }^{14}$ Os prémios do jogo do bingo estão sujeitos ao imposto do selo à taxa de $25 \%$, nos termos do $\operatorname{art}^{\circ} 1^{\circ}{ }^{\circ}$, n. $^{\circ} 1$, do Código do Imposto do Selo (CIS), conjugado com o n..$^{\circ} 11.2 .1$ da respectiva tabela geral anexa.

15 Tomemos por exemplo o caso da roleta francesa ou americana; a velocidade com que são feitas as múltiplas apostas possíveis, bem como o indefinível número de jogadores (e de espectadores) que em cada momento pode rodear uma banca de jogo, não permitiriam nem a criação das condições mínimas necessárias à contabilização e registo dos resultados, nem a manutenção do ambiente adequado à prática do jogo; não sendo ainda de afastar a possibilidade de surgirem conflitos com, e entre, jogadores, que tanto o vazio da espera como a ansiedade poderiam estimular. 
Genericamente falando, o fundamento maior da tributação reside na necessidade, por parte dos Estados, em obterem receitas para financiamento das respectivas despesas públicas. Estas receitas advêm nomeadamente dos impostos aplicáveis aos rendimentos das pessoas singulares e colectivas, segundo regras que divergem em função da natureza das mesmas. No tocante às sociedades comerciais (as concessionárias dos casinos são sociedades comerciais), o art. $^{\circ} 104 .^{\circ}, n^{\circ} 2$, da CRP refere que a tributação das empresas incide fundamentalmente sobre o seu rendimento real ${ }^{16}$. O Código do Imposto sobre o Rendimento das Pessoas Colectivas português (CIRC) determina que este imposto é aplicável aos rendimentos obtidos pelos sujeitos passivos e nos respectivos períodos de tributação ( art. $^{\circ} 1^{\circ}{ }^{\circ}$ ), estabelecendo o art. $^{\circ} 2^{\circ}{ }^{\circ}$ n..$^{\circ} 1$, al. a), que são sujeitos passivos, entre outras entidades, as sociedades comerciais com sede ou direcção efectiva em Portugal; o art. $^{\circ} 3 .^{\circ}$, n. $^{\circ} 1, a l . a$ ), preceitua que o IRC incide sobre o lucro das sociedades comerciais (dentre outras pessoas colectivas) que exerçam uma actividade de natureza comercial, industrial ou agrícola, a título principal, sendo o lucro definido no n. $^{\circ} 2$ como a diferença entre os valores do património líquido no fim e no início do período de tributação; o art. $^{\circ}$ 4. $^{\circ}$ estatui que o imposto recai sobre a totalidade dos rendimentos das pessoas colectivas com sede ou direcção efectiva em Portugal, incluindo os rendimentos obtidos fora do território português.

Em consonância com o previsto no art. $^{\circ} 7 .^{\circ}$ do CIRC, o art. $^{\circ} 84 .^{\circ}$, n. $^{\circ} 2$, da Lei do Jogo estabelece que sobre o exercício da actividade do jogo, ou de qualquer actividade das empresas realizada por força dos contratos de concessão, não incidirá qualquer outro imposto, geral ou local, durante o período de vigência da concessão ${ }^{17}$, assim se evitando uma dupla

\footnotetext{
${ }^{16}$ No sistema de tributação português, o rendimento real das empresas é determinado com base nos registos constantes das respectivas contabilidades. Contudo, a existência de erros e irregularidades não possibilitam a determinação e quantificação direta e exata do lucro tributável, daí que tenha de se recorrer à avaliação indireta para o seu apuramento, a partir de indícios, presunções ou de outros elementos disponíveis. Por todos, Lopes, Cristina Maria da Mota: A Tributação por Métodos Indiretos - Uma análise do enquadramento jurisprudencial dos aspetos contabilístico-fiscais, Dissertação de Mestrado em Contabilidade e Finanças, Faculdade de Economia da Universidade de Coimbra, 2013, p. 85.

17 Sobre o sistema fiscal português em geral ver Silva, Vera Lúcio Godinho da: A Actual Estrutura do Sistema Fiscal Português, Tese de Mestrado, Universidade de Aveiro, 2010, pp. 20-24, consultado em 1 de Março de 2014, em 〈https://ria.ua.pt/bitstream/10773/3529/1/4765.pdf〉. Quanto à tributação especial do jogo ver DUARTE, Rui Pinto: "O Jogo e o Direito", Themis: Revista da Faculdade de Direito da UNL, 2001, Ano II, No 3, pp. 69-93, pp. 89-90; Mariano, Filipa Neto: Contratos Fiscais: Regime e Natureza, Dissertação de Mestrado em Direito na Área de Ciências Jurídicas Empresariais, da Universidade Nova de Lisboa, 2011, pp. $48-49$ e Teixeira, Glória (Coord.): Lexit - Códigos Anotados \& Comentados - IRC, 3. ${ }^{a}$ ed., Ginocar Produções, Outubro 2013, pp. 45-46. Também a este assunto se refere o Ac. STA, de 12 de Abril de 2012, proc. 077/12, consultado em 25 de Abril em <http://www.dgsi.pt/jsta.nsf/35fbbbf22e1bb1e680256f8e003ea931/3857c019a634084e802579f000352329?Open Document>.
} 
tributação económica. Não se encontram portanto sujeitas ao imposto de sisa as aquisições, por parte das concessionárias, dos prédios indispensáveis ao cumprimento das obrigações contratuais por aquelas assumidas; e também não incide contribuição autárquica sobre os prédios afectos às concessões de jogo (art. ${ }^{\circ} 92 .^{\circ}$ da Lei do Jogo ${ }^{18}$. No entanto, as empresas concessionárias encontram-se sujeitas ao regime tributário geral pelo exercício das suas demais actividades (art. ${ }^{\circ} 84 .^{\circ}$, n. $^{\circ}$ 4, da Lei do Jogo), como sucede, por exemplo, com as relativas à restauração e hotelaria. $\mathrm{O}$ imposto especial de jogo, que recai fundamentalmente sobre os resultados obtidos pela exploração do jogo de fortuna ou azar, tem portanto natureza de imposto especial ${ }^{19}$, atenta a peculiaridade de excluir qualquer outra tributação sobre aquela actividade, encontrando-se tal qualificação expressa no art. ${ }^{\circ} 84 .^{\circ}$, n. ${ }^{\circ} 1$, da Lei do Jogo $^{20}$.

Trata-se, além disso, de um imposto directo ${ }^{21}$, por incidir precisamente sobre os rendimentos, podendo definir-se rendimento (segundo a teoria do acréscimo patrimonial) como a soma do consumo com o incremento líquido do património ${ }^{22}$.

\section{SUJEITOS DA RELAÇÃO DO IMPOSTO ESPECIAL DE JOGO}

No lado activo da relação jurídica do imposto especial de jogo encontra-se o Estado. Trata-se, por conseguinte, de um imposto estadual ${ }^{23}$. Com efeito, apesar de estes réditos tributários entrarem directamente nos cofres do Estado, este afecta, posteriormente, uma determinada percentagem em benefício das áreas dos municípios onde se situam os casinos; mas tais municípios encontram-se apenas na situação de beneficiários, não sendo sujeitos desta relação jurídica de imposto ( art. $^{\circ} 84 .^{\circ}$, n. $^{\circ} 3$, da Lei do Jogo). A titularidade da posição

\footnotetext{
${ }^{18}$ Para efeitos de aplicação desta disposição, recai sobre o Instituto do Turismo (sucessor da Inspecção-Geral de Jogos) o dever de informar as entidades competentes sobre quais os prédios, adquiridos ou construídos pelas concessionárias do jogo, que se encontram afectados ao cumprimento das respectivas obrigações contratuais (art. ${ }^{\circ}$ 94. ${ }^{\circ}$, al. a), da Lei do Jogo).

19 Na óptica de Clímaco, "uma situação de quase 'ghetto' fiscal", entendendo que a tributação foi usada como forma de penalizar o consumo do jogo, também apelidada de "tributação do 'pecado'". A natureza do jogo levou a que se enveredasse pela política de restrição da oferta deste, contrariamente à clássica utilização da variável fiscal como meio de redução do consumo (Clímaco, op. cit., p. 491 e 493).

${ }^{20}$ Ver, a propósito da natureza especial deste imposto, Silva, op. cit., p. 13.

21 O tipo de impostos mais frequentes no actual sistema fiscal de estado social, que foi afastando progressivamente o tradicional peso dos impostos indirectos (Nabais, José Casalta: Reflexões sobre quem paga a conta do estado social, 2008, p. 12, consultado em 27 de Abril, em <http://www.estig.ipbeja.pt/ ac_direito/Casalta2008.pdf>.

22 Por todos, Silva, Silva, op. cit., p. 14. A distinção entre impostos directos e indirectos é bastante controversa, não cabendo aqui aprofundar este ponto; para uma panorâmica, Martinez, Soares: Direito Fiscal, 7. ${ }^{a}$ ed., Coimbra, Almedina, 1993, pp. 49-52.

${ }^{23}$ Martinez, op. cit., p. 630.
} 
activa do Estado vai de par com a circunstância de este deter o monopólio da actividade do jogo lícito.

No lado passivo da relação jurídica do imposto especial de jogo encontram-se as empresas concessionárias do jogo $\left(\operatorname{art}^{\circ}{ }^{8} 4^{\circ}{ }^{\circ}\right.$ n. ${ }^{\circ} 1$, da Lei do Jogo). É de notar que estas empresas, relativamente a outras actividades desenvolvidas fora da estrita exploração do jogo, assumem posição igual à dos sujeitos passivos da relação tributária constituída em consequência do desempenho dessas mesmas actividades ${ }^{24}$.

\section{MATÉRIA COLECTÁVEL E TAXAS}

\subsection{Jogos bancados}

\subsubsection{Regime geral}

Matéria colectável - A colecta do imposto sobre os jogos bancados ${ }^{25}$ desdobra-se em duas parcelas, resultando a primeira da aplicação de uma taxa sobre uma percentagem do capital em giro inicial ${ }^{26}$ (matéria colectável), sendo a segunda calculada por referência a uma taxa aplicada sobre a matéria colectável consistente numa percentagem dos "lucros" brutos ${ }^{27}$ das bancas (art. ${ }^{\circ} 85 .^{\circ}$, pontos 1) e 2), da Lei do Jogo).

No caso das bancas simples, a primeira parcela da matéria colectável é constituída pelo capital em giro inicial utilizado no mês anterior (art. ${ }^{\circ} 87 .^{\circ}$, n. $^{\circ} 1$, ponto A), al. a), da Lei

\footnotetext{
24 Assim, os lucros auferidos pelas empresas concessionárias do jogo por via da prática de outras actividades não relacionadas com a exploração do jogo (como por exemplo a hotelaria e a restauração) são tributados em sede de IRC (art. ${ }^{\circ} 84 .^{\circ}$, n. $^{\circ}$ 4, da Lei do Jogo). Sobre a tributação de tais actividades em sede de IRC ver também Ac. o STA, de 2 de Dezembro de 1998, proc. 017440/98, consultado em 25 de Abril em <http://www.dgsi.pt/jsta.nsf/35fbbbf22e1bb1e680256f8e003ea931/b22e08fa9f825641802568fc0039d466? Open Document\&ExpandSection=1\&Highlight=0,_Section1\#_Section1>.

${ }^{25}$ São bancados quando a empresa exploradora participa no jogo, perdendo ou ganhando conforme os jogadores ganhem ou percam; são não bancados quando os jogadores jogam entre si, limitando-se a concessionária a disponibilizar as instalações e materiais de jogo a troco do pagamento de determinado valor correspondente a uma percentagem dos valores em jogo. Apontamos como exemplo de jogo bancado, a roleta, e de jogo não bancado, o bacará chemin de fer (Rento, Altina, e Laureano, Abel: Direito do Jogo (Legislação Anotada), Lisboa, Quid Juris, 1991, p. 25, nota ao art. ${ }^{\circ} 4^{\circ} \mathrm{n}^{\circ} 1$, da Lei do Jogo).

26 Capital em giro inicial é o montante com que a banca é dotada para dar início ao jogo, que deve ser constituído "por uma colecção de fichas de vários valores, em quantidade tal que torne dispensável, tanto quanto possível, a realização de trocos com a caixa vendedora durante o seu funcionamento" (art. ${ }^{\circ} 57 .^{\circ}$ da Lei do Jogo).

${ }^{27} \mathrm{O}$ legislador terá querido referir-se a resultados brutos, isto é, aos montantes obtidos antes do apuramento das despesas com o funcionamento do próprio jogo. Doravante referir-nos-emos a "resultados brutos", em substituição da designação "lucros brutos".
} 
do Jogo); As taxas aplicáveis às bancas simples correspondem às seguintes percentagens sobre o capital em giro inicial, consoante as diferentes zonas de jogo e um factor de ordem temporal, do seguinte modo: Estoril: 0,75\%. Funchal, Algarve, Tróia, Vidago-Pedras Salgadas e Porto Santo: $0,1 \%$ no primeiro quinquénio, $0,15 \%$ no segundo quinquénio, $0,2 \%$ no terceiro quinquénio, $0,25 \%$ no quarto quinquénio e no quinto quinquénio, bem, como 0,55\% nos demais quinquénios; restantes zonas de jogo: 0,55\% (art. ${ }^{\circ} 85 .^{\circ}$, ponto 1 ), al. a), da Lei do Jogo). Quanto às bancas duplas, a primeira parcela da matéria colectável é igualmente composta pelo capital em giro inicial utilizado no mês anterior (art. ${ }^{\circ} 87 .^{\circ}$, n. $^{\circ} 1$, ponto A), al. a), da Lei do Jogo). E, ainda pelo que concerne às bancas duplas, o quadro de taxas incidentes sobre as percentagens do capital em giro inicial configura-se assim: Estoril: 1,2\%. Funchal, Algarve, Troia, Vidago-Pedras Salgadas e Porto Santo: 0,15\% no primeiro quinquénio, 0,25\% no segundo quinquénio, $0,3 \%$ no terceiro quinquénio, $0,35 \%$ no quarto quinquénio e no quinto quinquénio, bem como $0,9 \%$ nos demais quinquénios. Restantes zonas de jogo: 0,9\% (art. ${ }^{\circ} 85 .^{\circ}$, ponto 1), al. b), da Lei do Jogo).

Ao fazer incidir a primeira das referidas parcelas da tributação sobre a mera disponibilização do jogo ao público, independentemente dos resultados (positivos ou negativos) de cada sessão, a lei promove, mediante a oneração fiscal aplicada, o comprometimento das concessionárias na adequação racional da oferta do jogo à quantidade de pessoas que revelem interesse em jogar. Tal medida, apesar de se traduzir para a concessionária numa oneração adicional àquela que já a atinge enquanto parceira no jogo, está em sintonia com a intenção do legislador em limitar-se a dar vazão aos ímpetos do jogador, sem incentivar a criação de circunstâncias que possam levar a um aumento desregrado do jogo $^{28}$. Adicionalmente, resulta para o Estado num encaixe garantido (libertando-o de parte da aleatoriedade inerente a uma receita contingente), do qual necessita para, nomeadamente, pagar os custos da máquina inspectiva.

Refira-se que o desempenho de cada banca por sessão de jogo é imprevisível, quer no tocante aos resultados atingidos (positivos ou negativos e respectivos montantes) quer ao seu tempo de funcionamento (uma banca pode abrir no início da sessão, funcionar normalmente, e a dada altura encerrar por falta de jogo; reabrir, na expectativa de que à mesma afluam novos

28 Uma maior oferta de jogo pode levar a que o jogador se sinta mais tentado a jogar. É frequente ver-se jogadores a correrem freneticamente de banca para banca, fazendo apostas em jogos que se desenrolam em simultâneo, "convictos" de que aquele é o seu momento de sorte e que, se apostarem, poderão ganhar a dobrar, a triplicar, etc.. 
jogadores, e voltar a encerrar sem que o jogo se tenha reiniciado; ou pode uma banca abrir tempestivamente sem vir a funcionar por falta de jogadores ${ }^{29}$ ). Essa imprevisibilidade, que poderá contribuir para uma maior aleatoriedade dos resultados, não se reflectirá necessariamente nos gastos da concessionária, uma vez que esta tem de salvaguardar, em permanência, todas as condições que permitam a abertura (ou reabertura) das bancas que, a qualquer momento venham a ser necessárias para acolher com comodidade os jogadores presentes na sala.

Pelo que concerne à segunda parcela da matéria colectável, referida ao lucro bruto das bancas, e no tocante às bancas simples, resulta aquela da aplicação, ao capital em giro inicial, das seguintes percentagens: Algarve: 10\%; Espinho: 21\%; Estoril: 21\%; Figueira da Foz: 21\%; Funchal: 3\%; Tróia: 1\%; Vidago-Pedras Salgadas: 1\%; Porto Santo: 1\%; e Póvoa de Varzim: $21 \%$ (art. ${ }^{\circ} 87 .^{\circ}$, n. $^{\circ}$ 1, ponto $A$ ), al. b), da Lei do Jogo). Quanto às bancas duplas, a segunda parcela da matéria colectável, referida ao lucro bruto das bancas, resulta da aplicação, ao capital em giro inicial, das seguintes percentagens: Algarve: 15\%; Espinho: 35\%; Estoril: 35\%; Figueira da Foz: 35\%; Funchal: 4,5\%; Tróia: 2,5\%; Vidago-Pedras Salgadas: 2,5\%; Porto Santo: 2,5\%; e Póvoa de Varzim: $35 \%$ (art. ${ }^{\circ} 87 .^{\circ}$, n. $^{\circ} 1$, ponto A), al. b), da Lei do Jogo). No que respeita à segunda parcela, a incidir sobre a receita bruta da banca, o legislador optou por se abster de contabilizar o número das jogadas feitas em cada banca por sessão de jogo, bem como os valores das respectivas apostas, preferindo considerar o apuramento do resultado final diário. É que a multiplicidade de apostas admissível por jogada, em razão quer dos montantes em jogo, quer da diversidade daquelas ${ }^{30}$, acrescida da quantidade indefinível de jogadores (e espectadores) que podem estar à volta de uma mesa, tornaria impraticável qualquer tentativa de apuramento, jogada a jogada, das respectivas apostas, perdas e ganhos.

Taxas - Quanto à determinação da colecta mediante a aplicação duma taxa incidente sobre uma percentagem dos resultados brutos das bancas, o conjunto de taxas a ter em consideração é o seguinte: Funchal, Algarve, Tróia, Vidago-Pedras Salgadas e Porto Santo:

\footnotetext{
29 Saliente-se o facto de que não incidirá imposto sobre o capital em giro inicial das bancas abertas tempestivamente que não cheguem a funcionar por falta de jogadores $\left(\operatorname{ar}^{\circ}{ }^{\circ} 53 .^{\circ}\right.$, n. $^{\circ} 2$, da Lei do Jogo).

${ }^{30} \mathrm{Na}$ roleta, por exemplo, as apostas podem fazer-se nas chances múltiplas ou chances simples; nas primeiras pode apostar-se no pleno, no cavalo, na rua, no quadro, na linha, na dúzia, na coluna, no cavalo de dúzia e no cavalo de coluna; nas segundas aposta-se no par, no ímpar, no menor, no maior, no encarnado e no preto.
} 
$10 \%$ no primeiro quinquénio, $12,5 \%$ no segundo quinquénio, $15 \%$ no terceiro quinquénio, e $20 \%$ nos demais quinquénios. Restantes zonas de jogo: $20 \%$ (art. ${ }^{\circ} 85 .^{\circ}$, ponto 2 ), da Lei do Jogo).

O jogo é tributado com taxas que diferem consoante a zona em que se desenrola a respectiva actividade; as taxas são superiores nos casinos de maior projecção e, nos de menor projecção, as taxas crescem à medida (temporal) da execução dos contratos. Subjacente a tal diferença de tratamento estarão certamente razões de natureza económica, justificadoras da discriminação positiva aplicada aos estabelecimentos de menor projecção, com perspectivas de menor rentabilidade, aos quais são ainda cobradas taxas menores nos primeiros anos da exploração.

Diferentemente do que se passa com a generalidade das actividades económicas, nas quais a base de incidência da tributação é o lucro real apurado (art. ${ }^{\circ}$ s $104 .^{\circ}$ da CRP e $3 .^{\circ}$ do (IRC) $)^{31}$, a taxa do imposto especial de jogo incide sobre uma percentagem dos resultados brutos das bancas (acrescida da referida parcela da percentagem sobre o capital em giro inicial); isto é, não são tidas em conta, para efeito de fixação da respectiva taxa, as despesas inerentes ao exercício da actividade (donde relevam, com grande expressão, os gastos com o pessoal). O Estado, levado por razões de ordem moral, trata a indústria do jogo como uma realidade de excepção, parecendo querer demonstrar, com o regime especial de tributação criado32, que não pretende interferir no curso do jogo e se alheia das mais valias que lhe advêm da respectiva prática.

\subsubsection{Máquinas automáticas}

A tributação relativa às máquinas automáticas segue o regime estabelecido para os jogos bancados, com algumas especialidades relativas à determinação da matéria colectável, cujo valor se obtém, desde logo, mediante remissão para o estabelecido no tocante aos jogos praticados em bancas simples (art. ${ }^{\circ} 87 .^{\circ}$, n. $^{\circ}$ 1, ponto $C$ ), al. a), da Lei do Jogo). Por outro lado, o organismo fiscalizador fixa anualmente, de harmonia com as respectivas características e as circunstâncias que se verifiquem nas explorações, o capital que deve

31 Consistindo o lucro na diferença entre os valores do património líquido no fim e no início do período de tributação (n. ${ }^{\circ} 2$ do $^{\text {art. }^{\circ}} 3 .^{\circ}$ do CIRC).

32 A chamada "tributação do pecado" (Vasques, Sérgio: Os Impostos do Pecado: O Álcool, o Tabaco, o Jogo e o Fisco, Coimbra, Almedina, 1999, pp. 88-89 e Clímaco, op. cit., p. 490). 
considerar-se, para efeitos fiscais, como capital em giro inicial (art. $.^{\circ} 87 .^{\circ}$, n. $^{\circ}$, ponto $C$ ), al. b), da Lei do Jogo); este capital é fixado em relação a cada máquina oferecida à exploração ou, a solicitação da concessionária, por grupos de máquinas, sendo o imposto devido, nesta última hipótese, em relação ao referido capital, ainda que não funcionem todas as máquinas do grupo respectivo ( art. $^{\circ} 87 .^{\circ}$, n. $^{\circ} 1$, ponto $C$ ), al. c), da Lei do Jogo).

À semelhança do que se passa com os tradicionais jogos bancados, nas máquinas automáticas a concessionária disponibiliza um pré-determinado capital destinado ao jogo ${ }^{33}$ (que irá funcionar como a sua aposta, enquanto parceira do jogo, sendo que os resultados do jogo se traduzirão em ganho ou perda da concessionária, consoante o/s outro/s jogador/es perca $/ \mathrm{m}$ ou ganhe $/ \mathrm{m})$. Mas, para efeitos tributários, o montante considerado como capital em giro inicial nas máquinas automáticas é fixado anualmente quando nos demais jogos bancados releva o capital em giro inicial utilizado no mês anterior.

\subsection{Jogos não bancados}

\subsubsection{Regime geral}

Nos jogos não bancados, a matéria colectável, correspondente a uma percentagem da receita cobrada dos pontos (valor que se destina à concessionária), é apurada através do seguinte modo: em cada mesa de jogo existe uma caixa onde é lançado o produto da percentagem sobre os montantes em jogo, o qual constituirá a receita da concessionária; tal valor é obrigatoriamente anunciado em voz alta pelo pagador e só será lançado na caixa depois de destacados, de cadernetas fornecidas pelo serviço de inspecção, e inutilizados, bilhetes que perfaçam importância igual à anunciada; diariamente, por sessão e em relação a cada mesa de jogo, são registados em livro próprio, por espécies, o número das cadernetas, a quantidade dos bilhetes inutilizados e a totalidade das correspondentes importâncias; o somatório das importâncias registadas deve corresponder à totalidade dos montantes lançados nas caixas (art. ${ }^{\circ} 87 .^{\circ}$, n. $^{\circ} 1$, ponto $\left.\left.B\right)\right)^{34}$. A forma encontrada para o apuramento da matéria colectável nos jogos não bancados, sobre a qual vai recair a taxa do imposto especial de jogo,

33 Cujo montante será reforçado sempre que, em consequência dos pagamentos feitos ao/s jogador/es ganhador/es, aquele se mostre insuficiente para permitir a continuação do jogo.

${ }^{34}$ De acordo com o previsto no art. $^{\circ} 87 .^{\circ}$, n. ${ }^{\circ} 2$, da Lei do Jogo, tais registos serão feitos em máquinas de modelo a aprovar pela entidade com competência para fiscalizar o jogo o determinar. 
permite um duplo nível de controlo: por um lado, os valores que em cada jogada se destinam à concessionária (uma espécie de renda das instalações disponibilizadas e de aluguer do material de jogo, acrescida dos encargos pelos serviços prestados pelo pessoal envolvido) são "fiscalizados" pelos mais directos interessados no desfecho das jogadas (os jogadores, que jogam entre si, porque a casa não é parceira no jogo); por outro lado, os registos tornam possível aquilatar da conformidade dos montantes destinados à concessionária, dos quais vai ser extraída a receita fiscal do Estado.

As taxas do imposto sobre os jogos não bancados recaem sobre os montantes da percentagem que constitui a receita da concessionária, conforme exposto; identicamente ao que sucede nos jogos bancados, as taxas diferem conforme as zonas de jogo e a dimensão temporal da execução do contrato de concessão, correspondendo ao seguinte quadro: Funchal, Algarve, Tróia, Vidago-Pedras Salgadas e Porto Santo: 5\%, 6\% e 7,5\% sobre a receita cobrada dos pontos, respectivamente no primeiro, segundo e terceiro quinquénios, $10 \%$ no quarto quinquénio e no quinto quinquénio, bem como $20 \%$ nos demais quinquénios. Restantes

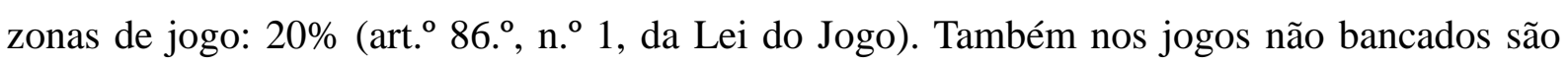
aplicadas taxas superiores de imposto, nos casinos de maior projecção; a discriminação positiva que se verifica neste tipo de jogos em prol dos estabelecimentos de menor projecção é acentuada pela aplicação de taxas ainda menores nos primeiros anos da exploração.

\subsubsection{Regimes especiais}

Jogo do bingo - É um jogo de fortuna ou azar não bancado (art. ${ }^{\circ} 2^{\circ}{ }^{\circ}$, n. ${ }^{\circ}$ 1, do Dec.-Lei n. $31 / 2011$, de 4 de Março, doravante designado por Lei do Bingo), praticado em salas instaladas em casinos e em salas próprias fora dos casinos, sendo estas concessionadas pelo Estado a pessoas colectivas públicas ou privadas ( $\operatorname{art}^{\circ}{ }^{\circ} \mathrm{s} 6 .^{\circ}$, n..$^{\circ} \mathrm{s} 1$ e 2 , e $7 .^{\circ}$ da Lei do Bingo). A receita bruta que reverte para as concessionárias (sobre a qual vai recair a tributação) difere consoante se trate da exploração do jogo do bingo em casinos ou fora destes: nos casinos, $40 \%$ da receita bruta proveniente da venda dos cartões de bingo constitui a receita da casa, enquanto nas salas fora dos casinos a casa fica com $35 \%\left(\right.$ art. $^{\circ} \mathrm{s} 27 .^{\circ}, \mathrm{n} .^{\circ} 1$ e $28 .^{\circ}, \mathrm{n} .^{\circ}$ s 1 e 2 , da Lei do Bingo).

Nos casinos, e para a determinação da matéria colectável, que é calculada com referência às receitas destinadas às concessionárias, são tomadas em consideração taxas 
diferentes consoante o volume de receitas e um factor de cariz temporal. Assim, e para um volume de receitas até 150.000 contos anuais: Funchal, Algarve, Tróia, Vidago-Pedras Salgadas e Porto Santo: 5\%,6\% e 7,5\% sobre a receita cobrada, respectivamente no primeiro, segundo e terceiro quinquénios, $10 \%$ no quarto quinquénio e no quinto quinquénio, bem como $20 \%$ nos demais quinquénios; restantes zonas de jogo: 20\%. Para um volume de receitas entre 150.000 contos e 250.000 contos anuais: Funchal, Algarve, Tróia, VidagoPedras Salgadas e Porto Santo: $10 \%, 12 \%$ e $15 \%$ sobre a receita cobrada, respectivamente no primeiro, segundo e terceiro quinquénios, $20 \%$ no quarto quinquénio e no quinto quinquénio, bem como $40 \%$ nos demais quinquénios; restantes zonas de jogo: 40\%. Para um volume de receitas superiores a 250.000 contos anuais: Funchal, Algarve, Tróia, Vidago-Pedras Salgadas e Porto Santo: $15 \%, 18 \%$ e $22,5 \%$ sobre a receita cobrada, respectivamente no primeiro, segundo e terceiro quinquénios, $30 \%$ no quarto quinquénio e no quinto quinquénio, bem como $60 \%$ nos demais quinquénios; restantes zonas de jogo: $60 \%$ (art. ${ }^{\circ} 86 .^{\circ}$, n. $^{\circ} 2$, da Lei do Jogo $)^{35}$. Identicamente ao regime aplicável aos demais jogos de fortuna ou azar praticados em casinos, o jogo do bingo é tributado com taxas que diferem consoante a zona em que se desenrola a actividade; as taxas são superiores nos casinos de maior projecção e nos de menor projecção as taxas crescem à medida (temporal) da execução dos contratos. Subjacente à diferença de tratamento fiscal entre concessionárias estarão as mesmas razões de natureza económica, justificadoras de discriminação positiva em prol dos estabelecimentos de menor projecção, atentas as perspectivas de menor rentabilidade destes, aos quais são ainda cobradas taxas menores nos primeiros anos da exploração. Nas salas implantadas fora dos casinos, a exploração do jogo do bingo é tributável nos termos aplicáveis às demais actividades de natureza comercial ou industrial (art. ${ }^{\circ}$ s $2 .^{\circ}$, n. $^{\circ} 1$ e $3 .^{\circ}$, n. $\left.^{\circ} 1, a l . a\right)$ e $10 .^{\circ},{ }^{\circ} .^{\circ} 3$, do CIRC).

O valor bruto que se destina a prémios (sujeitos a tributação) também difere consoante se trate da exploração do jogo do bingo em casinos ou fora destes: nos casinos, $60 \%$ da receita bruta proveniente da venda dos cartões de bingo destina-se a prémios, enquanto nas salas fora dos casinos os prémios absorvem 55\% daquela receita ( $\operatorname{art}^{\circ}{ }^{\circ}$ s $27 .^{\circ}$, n. $^{\circ} 1$, da Lei do Bingo); no entanto, em todas as salas de jogo do bingo as respectivas concessionárias podem aumentar a percentagem da receita bruta a afectar aos prémios, por redução do valor que lhes é destinado

\footnotetext{
35 As importâncias referidas encontram-se expressas em "escudos" com poder aquisitivo referido ao ano de 1988 e são actualizadas, com efeitos a partir de 1 de Março de cada ano, tendo em conta o índice médio de preços no consumidor no continente, excluindo a habitação, publicado pelo Instituto Nacional de Estatística, arredondandose para a "dezena de contos imediatamente inferior" (art. ${ }^{\circ} 86 .^{\circ}$, n. $^{\circ} 3$, da Lei do Jogo).
} 
(art. ${ }^{\mathrm{o}} 28 .^{\circ}$, n. $^{\mathrm{o}}$ 3, da Lei do Bingo). Diferentemente do que acontece com os demais jogos de fortuna ou azar não bancados e bancados (sobre cujos prémios não incide tributação), os prémios do jogo do bingo são tributados em imposto do selo, à taxa de $25 \%$ (art. $.^{\circ} 1 .^{\circ}$, n. $^{\circ} 1$, do Código do Imposto do Selo, conjugado com o ponto n. ${ }^{\circ} 11.2 .1$ da tabela geral).

Jogo do keno - Apesar de se tratar de um jogo bancado, é aplicável do jogo do keno o regime tributário fixado para o jogo do bingo (art. ${ }^{\circ} 85 .^{\circ}$, ponto 3 ), da Lei do Jogo).

\section{COBRANÇA}

Regime comum - O imposto especial de jogo deve ser pago, em relação a cada mês, até ao dia 15 do mês seguinte, na tesouraria da Fazenda Pública do município respectivo, mediante guia emitida pela entidade com competência para a fiscalização do jogo e enviada à repartição de finanças competente ( art. $^{\circ} 88 .^{\circ}$ da Lei do Jogo).

Regime de avença - A lei admite a possibilidade de o imposto especial de jogo ser pago por avença (art. ${ }^{\circ} 89 .^{\circ}$, n. $^{\circ} 1$, da Lei do Jogo). Através da avença o Estado acorda com a concessionária do jogo a determinação antecipada do valor da matéria colectável, sobre a qual recairá a taxa do imposto a aplicar e os termos dos respectivos pagamentos, ou então, a alteração do valor presumido e/ou dos termos dos pagamentos estabelecidos em avença anterior (porque o pagamento do imposto pelas vias normais da tributação implica incómodos que a opção pelo apuramento antecipado da matéria colectável presumida pode resolver) ${ }^{36}$.

Para efeito do estabelecimento da avença há lugar a um procedimento administrativo extremamente simples: o pedido da concessionária é dirigido à entidade com competência para a fiscalização do jogo; esta procede à instrução do referido pedido; a decisão final, tomada mediante despacho conjunto dos membros do Governo com tutela na administração fiscal e no sector do turismo, quando positiva, dá lugar à constituição do regime de avença, à sua revisão quanto ao quantitativo, ou à respectiva prorrogação por novos períodos (art. ${ }^{\circ}$ 89. , n. ${ }^{\text {o }}$, da Lei do Jogo).

A avença não poderá ser estabelecida por período inferior a seis meses ou superior a vinte e quatro meses, quanto às zonas de jogo permanente, e inferior a seis meses ou superior a doze meses, relativamente às zonas de jogo temporário ( art. $^{\circ} 89 .^{\circ}$, n. $^{\circ} 3$, da Lei do Jogo). A

\footnotetext{
${ }^{36}$ Mariano, op. cit., p. 49.
} 
liquidação do imposto segundo o regime de avença inicia-se no mês seguinte à manifestação da vontade consubstanciadora do respectivo acordo (art. ${ }^{\circ} 89 .^{\circ}$, n. $^{\circ} 4$, da Lei do Jogo).

\section{AFECTAÇÃO DAS RECEITAS}

Dos montantes provenientes do imposto especial de jogo, cobrado nos casinos, $77,5 \%$ constituem receita do Instituto do Turismo de Portugal, I.P. que, da importância recebida, aplica um montante igual a $20 \%$ na área dos municípios em que se localizem os casinos, na realização de obras de interesse para o turismo, e 2,5\% constituem receita do Fundo de Fomento Cultural, fundo autónomo com atribuições na área da promoção e difusão da cultura (art. ${ }^{\circ} 84 .^{\circ}$, n. ${ }^{\circ}$, da Lei do Jogo). As obras a efectuar nas áreas dos municípios em que se localizem os casinos obedecem a planos cujo estudo e elaboração compete a comissões nomeadas por portaria governamental para cada zona de jogo (sujeitos a aprovação do membro do Governo da tutela), sendo os respectivos pagamentos efectuados pelo Instituto do Turismo de Portugal, I.P. às entidades que superintendam na realização das obras (art. ${ }^{\circ}$ s 151 . $^{\circ}$, n. $.^{\mathrm{o}} 1,152 .^{\circ}$, n. $^{\mathrm{o}} 2$, e $154 .^{\circ}$, da Lei do Jogo).

Como oportunamente vimos, não incide imposto especial sobre o jogo do bingo fora dos casinos, estando a exploração deste sujeita a imposto sobre o rendimento das pessoas colectivas; as receitas provenientes deste imposto seguem o mesmo regime das receitas cobradas às demais empresas comerciais. Acrescente-se todavia que as concessionárias do bingo fora dos casinos canalizam para o Estado, embora sem natureza tributária, $10 \%$ da receita bruta da venda dos cartões de jogo, verbas a distribuir da seguinte forma: as provenientes das salas de concessionárias que não sejam clubes desportivos, ao Instituto Português da Juventude, I. P. (10\%), às entidades regionais de turismo em cuja área de jurisdição sejam geradas as receitas (45\%) e ao Instituto do Turismo de Portugal, I. P. (45\%); as provenientes das salas concessionadas a clubes desportivos, ao Instituto do Desporto de Portugal, I. P. (75\%) e ao Instituto do Turismo de Portugal, I. P. (25\%) (art. ${ }^{\circ} 29 .^{\circ}$ da Lei do Bingo). Tais receitas destinam-se a cumprir análoga função à desempenhada pelas empresas sujeitas a imposto especial de jogo. 
A associação da prática/exploração dos jogos de fortuna e azar ao turismo é entre nós basilar $^{37}$ (e uma constante desde os primórdios da sua legalização). A afectação de grande parte das receitas dos impostos sobre o jogo para fins de natureza turística é, portanto, uma consequência lógica, tendo sempre o Estado visto o jogo de fortuna ou azar como um precioso instrumento no projecto de desenvolvimento do turismo em Portugal.

\section{FISCALIZAÇÃO}

Em termos gerais, a fiscalização dos jogos de fortuna ou azar compete ao Instituto do Turismo de Portugal, I.P., entidade pública responsável pela promoção, valorização e sustentabilidade da actividade turística em Portugal, que em 2007, no âmbito do Programa de Reestruturação da Administração Central do Estado, sucedeu nas atribuições da extinta Inspecção-Geral de $\operatorname{Jogos}^{38}$ (conjugação do art. ${ }^{\circ} 90 .^{\circ}$ da Lei do Jogo com art. ${ }^{\circ} 3 .^{\circ}$, n. $^{\circ}$ 2, al. l), do Dec.-Lei n. ${ }^{\circ}$ 129/2012, de 22 de Junho). Tal competência é desempenhada pelo Serviço de Inspecção de Jogos, serviço com autonomia técnica e funcional (art. ${ }^{\circ} 15^{\circ}$, n. $^{\circ}$ 1, do Dec.-Lei n. ${ }^{\circ}$ 11/2014, de 22 de Janeiro (Lei Orgânica do Ministério da Economia), que desenvolve a actividade junto dos casinos e salas do jogo do bingo, através de inspectores superiores do Estado.

A fiscalização da escrita comercial das concessionárias e as respectivas obrigações fiscais é exercida sem prejuízo das competências do organismo do Estado com superintendência no sector tributário ( art. $^{\circ}$ 96. ${ }^{\circ}$, n. ${ }^{\circ}$ 3, da Lei do Jogo), a quem a fiscalização dos demais impostos incidentes sobre as empresas concessionárias.

\section{APRECIAÇÃO CRÍTICA GLOBAL}

\footnotetext{
$37 \mathrm{Na}$ actualidade, a ligação entre o mundo do jogo e a actividade turística não se observa na maior parte dos países europeus. Identicamente ao que se passa em Portugal, onde, a par dos jogos de fortuna ou azar, os casinos organizam eventos de natureza cultural e social, encontramos a Bélgica, a República Checa, a França, o Luxemburgo e a Eslováquia. Na Áustria, Dinamarca, Estónia, Finlândia, Alemanha, Letónia, Malta, Holanda e Suécia, os casinos não estão obrigados a desenvolver outras actividades para além do jogo (Swiss Institute of Comparative Law, Study of Gambling Services in the Internal Market of the European Union, Final Report 14 June 2006, p. vii, consultado em 18 de Junho de 2014, em <http://ec.europa.eu/internal_market/gambling/docs/study1_en.pdf >).

38 Art. $^{\circ}$ 24. $^{\circ}$, n. ${ }^{\circ}$ 1, do Dec.-Lei n..$^{\circ}$ 141/2007, de 27 de Abril, que definiu a missão e as atribuições do Instituto do Turismo de Portugal, I.P.
} 
Desde que entrou no domínio da legalidade, o jogo de fortuna ou azar sempre foi objecto de tratamento ambíguo; se por um lado o Estado o vê como algo nefasto, proibindo a sua livre exploração pelos privados (por razões de ordem moral e invocada necessidade de protecção dos jogadores), por outro lado permite a sua prática, embora sob forte regulamentação, em zonas de concessão obrigatória, tratando o mesmo jogo como indiscutível gerador de receitas que considera fundamentais para o desenvolvimento das regiões onde os casinos são implantados ${ }^{39}$; no entanto, o intrincado problema da ludopatia ${ }^{40}$, principal causa de problemas e de distúrbios sociais, não tem merecido do legislador o cuidado devido. Sob o signo da indefinição, a lei vem definindo as regras da exploração e prática do jogo ora apontando o dedo aos jogadores, pela não abonável conduta, ora chamando-os para a respectiva prática, que lhes serve com requinte e privacidade garantida. E apesar de aqui e além dar sinais de alguma preocupação com a salvaguarda de interesses das pessoas mais vulneráveis $^{41}$, a lei faz centra-se no lado económico do jogo ${ }^{42}$ (a sua vertente fiscal e, mais acentuadamente, a vertente contratual) relegando para segundo plano assuntos de grande alarme social, como a ludopatia e certa criminalidade associada ao jogo (branqueamento de capitais, corrupção, fraude, entre outros crimes), a cuja prevenção deveria acudir com urgência, por recurso, preferencialmente, às receitas provenientes do jogo.

Em matéria de tributação, a acção do legislador também não está isenta de crítica. Em geral as sociedades comerciais são tributadas com base, fundamentalmente, no seu rendimento real. Mas tal não sucede com a exploração dos jogos de fortuna ou azar em que o

\footnotetext{
${ }^{39}$ Deus refere-se a uma visão institucional acerca das vantagens turísticas da implantação de um casino em certa zona de jogo como "quase irrefutáveis" (Deus, José Pereira de: A Relevância do Casino para a Promoção e Consolidação da Imagem da Área-Destino, dissertação de Mestrado, Universidade de Aveiro, 2005, p. 5, consultado em 21 de Janeiro de 2014, em 〈http://ria.ua.pt/bitstream/10773/8979/1/207593.pdf〉

40 Em 2011, a Comissão Europeia referindo-se à ludopatia, deu nota de que "estudos recentes revelaram semelhanças entre dependência do jogo e toxicodependência" (Comissão Europeia, Livro Verde sobre o jogo em linha no mercado interno, COM(2011) 128 final, p. 23, consultado em 20 de Junho de 2014 em $<$ http://www.infoeuropa.eurocid.pt/opac/?func=service \&doc_library=CIE01\&doc_number=000046971\&line_nu mber $=0001 \&$ func code $=$ WEB-FULL\&service type=MEDIA $>$ ).

41 Tal preocupação é visível nomeadamente nas medidas restritivas de acesso às salas de jogos, impostas aos jogadores com algumas fragilidades, numa clara atitude protectora dos seus interesses, bem como na criação, e permanente fiscalização, das normas que regulam a exploração e a prática dos jogos, as quais são norteadas por princípios de interesse e ordem pública (art. ${ }^{\circ} 95 .^{\circ}$, n. $^{\circ} 2$, da Lei do Jogo).

42 Veja-se, por exemplo, o teor do Dec.-Lei n. ${ }^{\circ}$ 15/2003, de 30 de Janeiro, que autoriza a exploração de um segundo casino na zona de jogo do Estoril (Casino Lisboa), por razões que se prendem com a invocada existência de lacunas, em Lisboa, em matéria de animação, referindo que os casinos têm sido postos "ao serviço do turismo e da cultura", e que estes têm contribuído "para o enriquecimento e diversificação da oferta turística local, regional e nacional" (preâmbulo do diploma). Camillieri, não hesita em apelidar as políticas adoptadas em matéria de jogos de fortuna ou azar, de mercantilistas, porque os Estados se aproveitam dos jogadores para chegarem ao "bolo", deixando para aqueles somente algumas "migalhas" (Camillieri, op cit., p. 197).
} 
imposto incide sobre o rendimento bruto da actividade, com excepção do jogo do bingo praticado fora dos casinos, que segue o figurino de tributação das demais sociedades comerciais. Perante empresas da mesma natureza, cujas actividades prosseguem, de idêntica forma, a obtenção do lucro, que razões justificarão tal disparidade fiscal?

Ao não permitir que as concessionárias abatam à matéria colectável o valor dos gastos com a actividade do jogo, impondo a aplicação do imposto sobre as respectivas receitas brutas, o Estado está a tratar diferentemente aquelas concessionárias face às demais empresas comerciais, numa aparente tentativa de demonstrar que pretende refrear a oferta do jogo; no entanto, se fosse esse o objectivo, por que razão deixaria livre de tributação os prémios dos jogos praticados nos casinos (contrariamente ao que sucede com os jogos sociais e com o jogo do bingo), quando tal isenção é susceptível de aumentar o nível de estímulo ao jogo? Sempre se poderia afirmar, em abono da não tributação de tais prémios, que relativamente a alguns jogos de fortuna ou azar (roletas, banca francesa, ponto e banca, black-jack, para não mencionar outros) não se vislumbra nada fácil idealizar um sistema que permita a contabilização e o registo de cada aposta, seu resultado e identificação do apostador, para posterior aplicação do imposto, sem que para tanto a dinâmica do jogo não resulte profundamente afectada, quiçá paralisada ${ }^{43}$; mas tal argumento não poderá ser usado no campo das máquinas automáticas (cujos jogos assumem hoje maior relevância nos nossos casinos, tanto em afluência como em resultados), uma vez que nestas tudo se processa por via electrónica.

As referidas desigualdades, com claros objectivos extra-fiscais, não se fundando em razões ligadas à capacidade económica dos visados ${ }^{44}$, dificilmente se justificarão à luz do princípio da igualdade, conforme consagrado constitucionalmente; e não concorrerão para a diminuição do jogo na medida em que, apesar de proibida a sua oferta por particulares, através do jogo concessionado o jogador sente-se acolhido e desejado, pois este encontra-se disponível em ambientes seleccionados, especialmente dotados de conforto e privacidade;

43 Tomemos por referência o jogo das roletas (francesa ou americana). A velocidade com decorre a multiplicidade das apostas, bem como o indefinível número de jogadores (e de espectadores) que em cada momento rodeia uma banca de jogo, não permitiriam nem a criação das condições mínimas necessárias à contabilização dos resultados, nem a manutenção do ambiente adequado à prática do jogo; não sendo de afastar a possibilidade de surgirem conflitos com e entre jogadores, que tanto o vazio da espera como a ansiedade poderiam estimular.

44 Reza a Constituição que o imposto sobre o rendimento pessoal (o imposto sobre os prémios dos jogos de fortuna ou azar inserir-se-ia nesta categoria) deve visar a diminuição das desigualdades e ter em conta as necessidades e os rendimentos do contribuinte (art. $.^{\circ} 104 .^{\circ}$, n. $^{\circ} 1$, da CRP). 
nestas circunstâncias, a não tributação dos prémios concorre ainda para um acrescido incentivo a jogar ${ }^{45}$.

Em defesa da igualdade de tratamento fiscal sobre a exploração do jogo de fortuna ou azar e as demais actividades de natureza comercial e industrial, inclinamos para a desejabilidade de o regime de tributação do jogo passar a incidir sobre o lucro real apurado pelas respectivas concessionárias. Ao não vislumbrarmos qualquer fundamento que justifique o diverso tratamento de qua são alvos os prémios do bingo, os percebidos através das máquinas automáticas e os atribuídos pelos demais jogos praticados nos casinos, entendemos que urge repor a igualdade entre todos os ganhadores de prémios provenientes da prática de todos os jogos de fortuna ou azar. Esta medida, para além de nos parecer imprescindível perante os ditames constitucionais, teria a virtude de concorrer para o desincentivo deste tipo de jogos, objectivo presente em todos os normativos que regulam a matéria.

\section{CONCLUSÃO}

$>\quad$ As receitas provenientes da exploração do jogo de fortuna ou azar, bem como as geradas por outras actividades a que as empresas concessionárias dos casinos se encontrem adstritas por força da concessão, estão sujeitas apenas ao imposto especial de jogo, não incidindo outro imposto sobre esta, ou sobre qualquer actividade das empresas concessionárias realizada por força dos contratos de concessão.

Os valores pagos aos jogadores a título de prémios, com excepção do jogo do bingo, não são objecto de tributação.

O imposto especial de jogo, recaindo fundamentalmente sobre os resultados obtidos pela exploração do jogo, tem pois a natureza de imposto especial. É também um imposto directo, já que incide sobre os rendimentos obtidos.

45 Estamos com Zornoza quando o autor apelida os poderes públicos de hipócritas por criarem normas que restringem a exploração do jogo por privados (por apontadas razões ligadas a riscos morais) ao mesmo tempo que favorecem e até fomentam o jogo público (Zornoza PÉrez, op. cit., p. 168). 
No lado activo da relação jurídica do imposto especial de jogo encontra-se o Estado, tratando-se por conseguinte dum imposto estadual. No lado passivo da relação jurídica do imposto especial de jogo encontram-se as empresas concessionárias do jogo.

D A matéria colectável e as taxas deste imposto diferem, consoante se trate de jogos bancados ou de jogos não bancados. Em relação aos jogos bancados, distingue-se ainda entre um regime geral e um regime específico relativo às máquinas automáticas. Quanto aos jogos não bancados, opera-se também uma destrinça entre um regime geral e regimes específicos dos jogos do bingo e keno.

O imposto especial de jogo deve ser pago mensalmente, nas tesourarias da Fazenda Pública, mas a lei admite a possibilidade do seu pagamento por avença.

$>\quad$ A afectação das receitas do imposto especial de jogo cobrado nos casinos espelha a basilar associação dos jogos de fortuna e azar ao turismo, com 77,5\% daquelas receitas destinadas ao Instituto do Turismo de Portugal, I.P.

$>$ A fiscalização do imposto especial de jogo cabe na esfera de competências do organismo do Estado com tutela sobre o jogo (Instituto do Turismo de Portugal, I.P., que é exercida através do Serviço de Inspecção de Jogos), encontando-se os restantes impostos das empresas concessionárias sob a acção inspectiva do organismo do Estado com superintendência no sector tributário geral.

$>\quad$ O regime do imposto especial de jogo é passível de crítica. Ao não permitir que as concessionárias abatam à matéria colectável o valor dos gastos com a actividade do jogo, fazendo recair a tributação sobre as respectivas receitas brutas, o Estado trata diferentemente aquelas concessionárias face às demais empresas comerciais. Não se fundando em razões atinentes à capacidade económica dos visados, esta discrepância, com claros objectivos extrafiscais, dificilmente se justifica à luz do princípio constitucional da igualdade: com efeito, este regime não concorre para a diminuição do jogo, pois, através do jogo concessionado, disponível em ambientes seleccionados, especialmente dotados de conforto e privacidade, o 
jogador acaba por se sentir acolhido e desejado; e a não tributação dos prémios acaba por se traduzir num adicional incentivo a jogar.

Pelas razões atrás expendidas, defendemos o estabelecimento da igualdade de tratamento fiscal entre a exploração do jogo de fortuna ou azar e as demais actividades de natureza comercial e industrial, e também entre todos os prémios atribuídos aos jogadores de qualquer espécie dos referidos jogos.

\section{REFERÊNCIAS}

Barnes, Steve: "The Real Cost of Casinos: A Health Equity Impact Assessment", Wellesley Institute, January 2013, consultado em 13 de Fevereiro de 2014, em <http://www.wellesleyinstitute.com/wp-content/uploads/2013/01/Real-Cost-of-a-

Casino_Wellesley-Institute_2013.pdf>

Brenner, Reuven, e Brenner, Gabrielle: Spéculation et jeux de hasard: Une histoire de l'homme par le jeu, Paris, Presses Universitaires de France, 1993

Camillieri, Sébastien: Les finances publiques et le jeu, Thèse de doctorat, Université Jean Moulin Lyon 3, décembre 2008, consultado em 29 de Maio de 2014, em <http://theses.univlyon3.fr/documents/getpart.php?id=1472\&action=pdf >

Clímaco, Maria Isabel Namorado, "Os Jogos de Fortuna ou Azar - O lazer tolerado ou o 'vício' legalizado?" in Sanches, J. L. Saldanha e Martins, António: Homenagem a José Guilherme Xavier de Basto, Coimbra Editora, 2006

Cnossen, Sijbren (ed.), Forrest, David, e Smith, Stephen: Taxation and Regulation of Smoking, Drinking and Gambling in the European Union, The Hague, CPB Netherlands Bureau for Economic Policy Analysis, 2009

Comissão Europeia, Livro Verde sobre o jogo em linha no mercado interno, COM(2011) 128 final, consultado em 20 de Junho de 2014 em <http://www.infoeuropa.eurocid.pt/opac/?func=service\&doc_library=CIE01\&doc_number=0 00046971\&line_number=0001\&func_code=WEB-FULL\&service_type=MEDIA >

Deus, José Pereira de: A Relevância do Casino para a Promoção e Consolidação da Imagem da Área-Destino, dissertação de Mestrado, Universidade de Aveiro, 2005, consultado em 21 de Janeiro de 2014, em http://ria.ua.pt/bitstream/10773/8979/1/207593.pdf

Deus, José Pereira de, e Lé, António Jorge: O Jogo em Portugal, Coimbra, Minerva, 2001 Erreguerena Albaitero, José Miguel: "Aspectos fiscales de los juegos de azar en México", in Mora-Donatto, C. (coord.): Juegos de azar. Una visión multidisciplinaria, México, Universidad Nacional Autónoma de México, 2010, pp. 133-163 
Gomes, Maria Margarida Carqueijeiro Tomaz, A Política Pública das Lotarias, Instituto Superior de Economia e Gestão da Universidade Técnica de Lisboa, 2007

Grinols, Earl L., e Mustard, David B.: "Business Profitability versus Social Profitability: Evaluating Industries with Externalities, The Case of Casinos", Managerial and Decision Economics, 2001, Vol. 22, pp. 143-162

Jimenez Rea, Ovidio: Incidencia contable y tributaria del juego en casinos y máquinas tragamonedas en los fines extrafiscales del Estado, Tesis para optar el Grado Académico de Magister en Contabilidad con mención en Política y Administración Tributaria, Universidad Nacional Mayor de San Marcos, Facultad de Ciencias Contables, Lima (Perú), 2012, $\begin{array}{lllllll}\text { consultado em } 12 \text { de } & \text { Fevereiro }\end{array}$ <http://cybertesis.unmsm.edu.pe/bitstream/cybertesis/2664/1/jimenez_ro.pdf>

Lopes, Cristina Maria da Mota: A Tributação por Métodos Indiretos - Uma análise do enquadramento jurisprudencial dos aspetos contabilístico-fiscais, Dissertação de Mestrado em Contabilidade e Finanças, Faculdade de Economia da Universidade de Coimbra, 2013

Mariano, Filipa Neto: Contratos Fiscais: Regime e Natureza, Dissertação de Mestrado em Direito na Área de Ciências Jurídicas Empresariais, da Universidade Nova de Lisboa, 2011 Martinez, Soares: Direito Fiscal, 7. a ed., Coimbra, Almedina, 1993

Massin, Sophie: "Étude socio-économique des jeux de hasard et d'argent en France", Rapport d'étape $\mathrm{n}^{\circ}$ 2, Observatoire des Jeux, 20 février 2013, consultado em 16 de Junho de 2014, em <http://www.economie.gouv.fr/files/Etude\%20économique\%20rapport\%20d'etape\%202.pdf>

Nabais, José Casalta: Reflexões sobre quem paga a conta do estado social, 2008, consultado em 27 de Abril, em <http://www.estig.ipbeja.pt/ ac_direito/Casalta2008.pdf>

Pessanha, Luís: "O Jogo de Fortuna e Azar e a Promoção do Investimento em Macau", Administração: Revista da Administração Pública de Macau, 2007-3º, Vol. XX, No 77, pp. 847-888

Piçarra, Nuno: "Anotação ao acórdão do Tribunal de Justiça da União Europeia, de 8 de Setembro de 2009, Liga Portuguesa de Futebol Profissional e Bwin International Ltd contra Departamento de Jogos da Santa Casa da Misericórdia de Lisboa, C-42/07", in Duarte, Maria Luísa e. a. (coord.): 20 Anos de Jurisprudência da União sobre Casos Portugueses. O que fica do diálogo entre os juízes portugueses e o Tribunal de Justiça da União Europeia, Lisboa, 2011, pp. 311-334

Pinheiro, Januário, Lei do Jogo, Anotada e Comentada, Coimbra, Almedina, 2006 Pinto, Mota, Monteiro, Pinto, e Silva, Calvão da: Jogo e Aposta - Subsídios de Fundamentação Ética e Histórico-Jurídica, apontamentos copiografados, Lisboa, Católica Portuguesa, s.d.

RENTO, Altina, e LAUREANO, Abel: Direito do Jogo (Legislação Anotada), Lisboa, Quid Juris, 1991 
Silva, Vera Lúcia Godinho da: A Actual Estrutura do Sistema Fiscal Português, Tese de Mestrado, Universidade de Aveiro, 2010, consultado em 1 de Março de 2014, em <https://ria.ua.pt/bitstream/10773/3529/1/4765.pdf>

Swiss Institute of Comparative Law, Study of Gambling Services in the Internal Market of the European Union, Final Report 14 June 2006, consultado em 18 de Junho de 2014, em <http://ec.europa.eu/internal_market/gambling/docs/study1_en.pdf>

Teixeira, Glória (Coord.): Lexit - Códigos Anotados \& Comentados - IRC, 3. ${ }^{\mathrm{a}}$ ed., Ginocar Produções, Outubro 2013

Vasques, Sérgio: Os Impostos do Pecado, o Álcool, o Tabaco, o Jogo e o Fisco, Coimbra, Almedina, 1999

Zornoza Pérez, Juan: "La tributación de los juegos de azar: Una perspectiva comparada", in Mora-Donatto, C. (coord.): Juegos de azar. Una visión multidisciplinaria, México, Universidad Nacional Autónoma de México, 2010, pp. 165-182

Ac. STA, de 12 de Abril de 2012, proc. 077/12, consultado em 25 de Abril em <http://www.dgsi.pt/jsta.nsf/35fbbbf22e1bb1e680256f8e003ea931/3857c019a634084e80257 9f000352329? OpenDocument>

Ac. TJUE 8 de Setembro de 2010, Liga Portuguesa de Futebol Profissional e Bwin International Ltd / Departamento de Jogos da Santa Casa da Misericórdia de Lisboa, C-42/07, c. n. ${ }^{\circ}$ 56, consultado em 25 de Abril em http://curia.europa.eu/juris/documen t.jsf?text $=\&$ docid $=77072 \&$ pageIndex $=0 \&$ doclang $=P T \&$ mode $=1$ st $\&$ dir $=\& o c c=$ first $\&$ part $=1 \& \mathrm{c}$ $\underline{\mathrm{id}=429168}$

Ac. STA, de 2 de Dezembro de 1998, proc. 017440/98, consultado em 25 de Abril em <http://www.dgsi.pt/jsta.nsf/35fbbbf22e1bb1e680256f8e003ea931/b22e08fa9f825641802568 fc0039d466?OpenDocument\&ExpandSection=1\&Highlight=0,_Section1\#_Section1> 